\title{
Beyond Corporate Social Responsibility: Public Value and the Business of Politics
}

\author{
Josie Fisher (Corresponding author) \\ School of Business, Economics and Public Policy, University of New England \\ Armidale, New South Wales 2351, Australia \\ Tel: 61-2-6773-3706 E-mail: jfisher@une.edu.au \\ Bligh Grant \\ Centre for Local Government, University of New England \\ Armidale, New South Wales 2351, Australia \\ Tel: 61-2-6773-3945_E-mail: bgrant5@une.edu.au
}

$\begin{array}{lll}\text { Received: January 22, } 2012 & \text { Accepted: February 25, 2012 } & \text { Published: April 1, } 2012 \\ \text { doi:10.5539/ijbm.v7n7p2 } & \text { URL: http://dx.doi.org/10.5539/ijbm.v7n7p2 }\end{array}$

\begin{abstract}
Recent accounts of the changing role of business have identified a shift from corporate social responsibility to specifically political roles. This paper examines the relevance of Mark Moore's theory of Public Value (1995) as a decision-making framework for these new roles. After providing an account of the original theory, we explore how it can be deployed as a prescriptive tool based upon Moore's (1995) account of public goods, virtue ethics and an account of civic virtue we derive from the theory. The discussion invites critical reflection upon the changing roles of business, specifically the distinction between public and private organisations.
\end{abstract}

Keywords: Corporate social responsibility, Corporate strategy, Democratic governance, Public value, Strategic management

\section{Introduction}

\subsection{Changing Nature of CSR - A Political Role for Business}

In discussing what they describe as a 'new perspective' on corporate social responsibility (CSR) Scherer and Palazzo $(2010,1)$ argue that 'during the past few decades business firms have started to engage in activities that have traditionally been regarded as actual government activities'. While previously CSR was defined first within an economic framework where the role of business was to maximise profits within the rule of law (Friedman, 1970) then by a normative/stakeholder approach in which competing perspectives were allowed to influence decision-making, according to Scherer and Palazzo $(2010,7)$ both these approaches built 'on the assumption of an intact nation-state system that provides the legal and moral point of reference'. In contemporary conditions of globalised markets, this framework has been significantly eroded.

While not unique in advancing this perspective (see, for example, Matten and Crane, 2005) it is important to distinguish Scherer and Palazzo's (2010) view from several others that attempt to depict the changing role of business. First, from the idea of 'corporate constitutionalism' where, following from the work of Davis (1960; 1967), business is urged to use its power responsibly. Second, from the idea of corporate citizenship, which views business as actors within civil society guided by principles such as sustainability and consumer rights (see, for example, Garriga and Melé, 2004). Third, the perspective of Scherer and Palazzo (2010) is qualitatively distinct from those that see an increase in what Lux, et al., (2011) refer to as Corporate Political Activity (CPA), wherein business increasingly attempts to influence politics in the form of, for example, political lobbying (see also, Reich, 2008). In this latter account, business is still framed as a distinct structural sphere of organisational activity which seeks increased influence upon a specifically political realm. By contrast, Scherer and Palazzo $(2010,1)$ are directing our attention to business taking over 'actual government activities'. 
As well as observing this general empirical trend, Scherer and Palazzo (2010, 8-9) construct a framework (our term) from which to consider the changing nature of CSR in more detail based upon five observations. First, what they term 'the emerging global/institutional context for CSR', in which national governments have ceded some of their regulatory impact to new forms of global governance, including multi-lateral institutions and private organisations (see, for example, Hearfield and Sorensen, 2009). Second, the development of 'CSR as self-regulation: from hard law to soft law', whereby non-governmental power operates to both enforce rules and censure behaviour (see Nye, 1990; 2004). Third, 'the expanding scope of CSR: from liability to social connectedness', where business is encouraged to look beyond legal liability and take more responsibility for their activities through social networks. Fourth, 'the changing conditions of corporate legitimacy: from cognitive and pragmatic legitimacy to moral legitimacy', requiring businesses to construct their own normative operational frameworks outside those provided by nation states. Finally, what Scherer and Palazzo $(2010,9)$ termed 'the changing social foundation of CSR: from liberal democracy to deliberative democracy', where private organisations augment the assumed legitimacy of representative democracy with legitimacy gathered from a variety of deliberative decision-making processes.

Scherer and Palazzo $(2010,19)$ also advanced a further important observation. Drawing from the work of Cutler (2001) they pointed out that '...it is unclear how and in what sense regulatory activities of private actors can be integrated into the established concept of democracy and how it could contribute to resolving the legitimacy problems of global governance'. They also asserted that:

While some authors have also proposed to take a closer look at deliberative democracy as a conceptual context for CSR ... others have criticised this philosophical shift for going too far ... or not far enough.... Further research efforts need to further address the challenges embedded in the shift from liberal to deliberative theory.

Scherer and Palazzo (2010) are thus acutely aware of the normative ambiguity surrounding the extension of CSR into the political realm and the challenges that this poses to theories of the firm. They are suggesting the requirement not merely to construct an accurate sociological heuristic but also an ethical framework to guide the actions of organisations and, in particular, the individuals within these organisations; to construct an ethics for these changed circumstances.

Indeed, one need only examine the websites of several prominent corporations to observe them moving from considerations of CSR to incorporate unfolding political roles into their activities. For example, since 2001 BHP Billiton has provided a series of reports dealing with issues of corporate social responsibility, such as environmental sustainability (BHP Billiton, 2010a). In the most recent of these documents, the corporation clearly broadens its ambit to include issues of service provision and organisation centred on the 'Community'. For example, commenting on its interface with stakeholder groups in remote communities, the Supplementary Sustainability Information 2010 states:

The range of topics discussed during these stakeholder consultation processes includes town amenity and housing, cultural preservation and heritage, impacts of growth and expansion projects, contractor management, security and crime, Indigenous issues and social development (BHP Billiton, 2010b, 14).

This excerpt indicates that BHP Billiton perceives its renewed ambit as not merely entailing the provision of nominated basic amenities ('housing'; 'security') but providing a range of more contestable goods ('cultural preservation and heritage'; 'social development'). Similar accounts are described by many corporations, including British American Tobacco (BAT, 2011), MacDonald's (2010) and AMP (2011). Yet the construction of these renewed ambits is, as Scherer and Palazzo (2010) suggest, far from uncontroversial.

\subsection{Public Value and CSR}

It is with a view to addressing this problem that this paper undertakes an application of Mark Moore's theory of Public Value to business ethics and CSR. Moore's theory was originally developed as an element of Harvard University's Kennedy School of Government program, and then put forward in Creating Public Value (1995). Recently this work has been the subject of rigorous scrutiny, investigating the cogency of the theory (see, for example, Stoker, 2006; O'Flynn, 2007; Talbot, 2009); its validity in a variety of public management settings, including Westminster systems of government (see, for example, Rhodes and Wanna, 2007; 2009) and local government systems (Gains and Stoker, 2009; Grant and Fisher, 2011). Public Value has also been discussed as an empirical phenomenon and has been analysed as an element of cross-national professional ethics in the public sector (Plant, et al., 2008), as a phenomenon specific to Western Europe (Charles, et al., 2010), in comparative Anglophone countries (Wallis and Gregory 2009) and as a feature of specific organisational practices ranging from management control systems (Spano, 2009), labour markets (Meynhardt and Metelmann, 2009) and in the context of developing countries' public organisations (Samaratunge and Wijewardena, 2009). 
In this paper, these debates form a backdrop to our discussion. Our central concern is to demonstrate how Moore's (1995) reinvigorated theory of public management can be used to inform emergent practices of business by providing a more detailed heuristic for these practices, as well as locating and informing the actions of managers within this changed environment. In essence, we undertake a critical examination of Moore's (1995) account of Public Value, and argue that it has much to offer the changed circumstances in which business now finds itself.

The paper proceeds by providing two accounts of Moore's (1995) theory: firstly, a simple account that Moore (1995) offers by way of example and secondly, the detail of the theory as set out in Creating Public Value (1995). We then examine the distinction between the public and the private in Moore's theory noting the differentiation between the two based on Moore's (1995) account of public goods and the legitimacy of the authority of government. Paradoxically, this difference can be juxtaposed with the similarity of the two spheres in the operational and strategic elements of Moore's (1995) theory. We then reflect upon the implications of this theory of ethical and organisational practices of business, arguing that Moore's conceptual scheme suggests an account of civic virtue that is directly applicable to business, that its focus upon deliberative decision-making provides an appropriate procedural account of both politics and the firm which is an advance on stakeholder accounts of CSR, and that it provides a positive ethos for corporate managers/CEOs in the changed circumstances identified by Scherer and Palazzo (2010).

\section{Defining Public Value}

\subsection{Simple Account of Public Value}

Moore (1995, 13-20) initially explains the idea of Public Value by way of example. He presents us with a (hypothetical) city librarian who is faced with the problem of the library being used as a de facto childminding facility for latch-key children waiting for their parents to finish work. The librarian's initial reaction is to take steps to stop this - the library is not a childminding facility - by publishing a letter in the local newspaper or introducing rules limiting the access. For Moore this (traditional) response is based upon what he labels as the 'important doctrine' mandating that the librarian's actions are prescribed by statute: The librarian is obliged to exercise an administrative/bureaucratic mindset, 'downward, toward the reliable control of organisational operations, rather than either outward, toward the achievement of valuable results, or upward, toward the achievement of re-negotiated political mandates' (Moore, 1995, 17).

Yet Moore continues to explore this scenario. In her deliberations concerning the problem of the latch-key children (Moore's librarian is gendered) the librarian conceives of other strategies leading to alternative outcomes: She (a) thinks the presence of the latch-key children can be used as a justification for asking for more funds for the library; she also (b) conceives a user-pays system based on a cost-recovery model of the children using the library; (c) the option of consulting the community about the use of the library occurs to her; as does (d) the idea of calling for volunteers to help staff the library when needed. Moreover, the librarian also (e) contemplates restructuring her own organisation within its existing resources in order to accommodate the children.

At this level Moore's point is straightforward, namely, that in thinking and imagining outside an 'administrative/bureaucratic mindset', the librarian can encourage and bring to fruition a situation where the public resources she is custodian of (and indeed, ones that she is able to garner with attendant justifications) are more valued in the sense that the library would be appreciated by a broader spectrum of the community, while at the same time responding to a need the community has for after school-care - in effect creating public value. Moore $(2005,15-16)$ also argues that we forgo the potential value public managers can create if they do not exercise this 'imagination', or 'entrepreneurial spirit'. Indeed, Moore suggests that many public managers think like this anyway, thus it's foolish to discourage them from so doing.

Moore $(1995,18)$ points out that in one sense the librarian, by exercising her imagination and acting upon a particular course of action, 'begins thinking as society expects private sector executives to think'. She is, after all, attempting to respond to the demand for an after-school childcare facility and exploiting an existing situation in this regard. However, acting this way is problematic because the library is a public facility and the librarian a public manager. In a public sector context, we do not have a justification for managers acting this way; we assume they are the mere conduits of public policy. Moore (1995) seeks a justification for managers not merely exercising their imagination, but acting upon it without turning to the polity for justification, and acting upon it repeatedly as the most valuable part of their job. Additionally and importantly, he wants to derive a concept of Public Value that can provide the basis for managerial behaviour in conditions of a plurality of values. This plurality of values exists due to both (a) different ideas about what is valuable, and (b) the fact that these 
perspectives are context-dependant.

\subsection{Theoretical Account of Public Value}

To construct his theory, Moore $(1995,28)$ begins with the controversial proposition that 'the aim of managerial work in the public sector is to create public value, just as the aim of managerial work in the private sector is to create private value'. Yet this equivalence only extends so far: Moore points out that while public and private organisations are similar in that they both produce goods and services (the former using public assets, the latter using private assets) public organisations also use authority, or legitimate coercion - in the first instance, to tax, but also to impose other kinds of costs upon individuals in order to achieve their goals. Consequently, for Moore $(1995,29)$, public managers aren't merely assessed on the basis of the goods and services produced; 'they must also be able to show that the results obtained are worth the cost ... forgone in producing the desirable results'.

According to Moore $(1995,29-30)$ the question of to whom this demonstration ought to be made is relatively straightforward - at least initially. Whereas in the market consumers exercise their sovereignty by voluntarily choosing particular products, thereby demonstrating preferences for particular outcomes, so in the political arena citizens choose representatives who in turn are supported by a bureaucracy complete with public managers. Again, the correlation is by no means absolute, 'individual voluntary choice does not control the [political] system' (Moore, 1995, 30). However, Moore argues that representative democracy is as close as we can reasonably come to replicating the mechanism of the market. In selecting our representatives, who then govern the political and administrative systems, we are selecting particular kinds of outcomes and the value encapsulated therein.

Yet according to Moore $(1995,31-38)$ over time the legitimacy of this public realm has proven problematic: Politicians have proven prone to corruption, and to attribute to the bureaucracy the characteristic of politically neutral competence is dangerously naïve. Moreover, the particular social scientific techniques that have been developed for measuring the effectiveness of public sector action, such as program evaluation and benefit-cost analysis, while offering both ex ante and post-facto evaluation, have inherent methodological biases. And any attempt to assess public action based upon the 'customer satisfaction' of citizens is flawed because by their nature, some public goods will inevitably be seen as undesirable by some citizens, although they will be valued by the majority of citizens (a good criminal justice system is hardly valued by criminals, for example).

At this impasse Moore makes an important claim with respect to his account of politics, and the relationship between this to both administration and the activity of individual managers:

In the end none of the concepts of 'politically neutral competence', 'policy analysis', 'program evaluation', or 'customer service' can finally banish politics from its preeminent place in defining what is valuable to produce in the public sector. Politics remains the final arbiter of public value just as private consumption decisions remain the final arbiter of private value. Public managers can proceed only by finding a way to improve politics and make it a firmer guide as to what is publically valuable. That is why political management must be part of our conception of what public managers do (Moore, 1995, 38)

The important point is the place of the manager in this public sector matrix, namely, their centrality to the political process and the fact that they are given a legitimate, decision-making and political role.

While this normative account of managerial behaviour may appear to prescribe for managers a 'box seat' (our phrase) in terms of making decisions about what to do with public goods, Moore $(1995,37)$ emphasises that public managers always operate in a context defined by three features. First, as bundles of fixed and variable assets, all public organisations are limited in their capacities. In this sense, the actions of managers are to an extent determined by the 'organisational context' in which they find themselves. As well, these assets are by no means 'entirely fungible': managers cannot dispose of public assets in the way that an individual can dispose of private property. On the contrary, they must provide legitimating narratives about the use of these assets. Second, managers operate alongside and are constantly interacting with what Moore $(1995,37)$ refers to as the 'authorising environment', within which there is significant disagreement about the deployment of these public assets. Politicians do not explicitly consent to all actions of public managers. Nevertheless, this authorisation is a constant presence. Finally, while particular processes within organisations will be producing outputs (goods or services) it is up to the manager to search for value-making opportunities within this context. In the case of our librarian, '[her] problem, then, is to judge in what particular ways the assets entrusted to [her] could be redeployed to increase the value of the enterprise for which [she] is temporarily responsible'. This organisational and ethical matrix Moore $(1995,22)$ labels the 'strategic triangle'. Alford and O'Flynn $(2009,173)$ have done us a service in depicting this model in Figure 1. 


\section{Insert Figure 1 here}

Examining Figure 1, it is important to note the distinction Moore makes between the three ideal-type spheres of action and the pivotal place attributed to value-producing managerial behaviour in relation to the other two. We will return to an augmented version of Figure 1 in the penultimate section of our discussion.

In this way, Moore (1995) drills down from the problems associated with the traditional sites for the justification of public action (the polity; the bureaucracy) and the techniques we have for its evaluation (program evaluation and benefit-cost analysis; customer satisfaction) to provide a structural (that is, political; institutional) justification of managerial autonomy. Notably, this justification resides in not only familiar criteria such as efficiency, responsiveness to the political realm and an altered account of managerial neutrality, but one where managers ought to seek to 'value-add' in their positions. While many of the justifications for government remain intact around the creation of Public Value, much now becomes contingent upon the role of public managers. This is why, even though the vast majority of Moore's text is a series of prescriptions for managers, or what he refers to as 'a normative (rather than a positive) theory of managerial (rather than organisational) behaviour' (Moore, $1995,1)$ at the same time it necessarily has 'to set out a philosophy of public management. That is, an idea of what we citizens should expect of public managers, the ethical responsibilities they assume in taking office and what constitutes virtue in the execution of their offices' (Moore: 1995, 1). In part four of the paper we will return to the content of Moore's (1995) idea of managerial virtue as a central element of our argument that this conceptual schema is directly applicable to business organisations in the changed circumstances identified by Scherer and Palazzo (2010).

\section{Public-Private in Public Value}

\subsection{Theoretical Delineation of Public-Private in Public Value}

Moore (1995) chooses to explain his theory of Public Value by continually comparing the public sector to the private sector. He draws a series of analogies between the two ideal types, and then introduces a caveat to each analogy to distinguish the public from the private. The first analogy stems from his proposition that 'the aim of the public sector is to create public value, just as the aim of managerial work in the private sector is to create private value' (Moore, 1995, 28). The caveat to this resides in the assessment of what is valuable: While for private organisations this is revealed by consumers exercising their preferences in the market, in public organisations this assessment is undertaken by the institutions of representative government.

Moore's $(1995,30)$ second analogy is between consumers and citizens exercising their preferences. The caveat here is that unlike the market (where individual preferences are constantly revealed) 'individual voluntary choice does not control the political system', but is expressed through the institutions of representative democracy. Third, despite the problems with demonstrating Public Value (imperfect politicians; bureaucratic mandarins) Moore (1995) encourages us to view citizens as consumers in their relationship with public goods. The caveat in this instance is that they are public goods (non-excludable, indivisible, jointly consumed) and that citizens are 'spending their freedom' when choosing them, that they are bought for everybody's benefit and that whole organisations rather than individual products are purchased. Moreover, the value of the authorising process is extremely important.

Forth, while managers in both sectors preside over the assets of their organisations, Moore $(1995,37)$ asserts that public assets are less fungible than private assets. Fifth, while Moore $(1995,53)$ draws a direct analogy between public and private managers in the dual nature of their accountability (private managers to consumers and shareholders; public managers to clients/consumers and citizens via the 'authorising environment'), he argues that public managers must nevertheless pay more attention to their authorising environment than private managers to shareholders. Finally, both organisational types are required to provide legitimating stories about their activities: 'In this sense a policy is to the public sector manager what a prospectus is to a private manager'. In this instance, the caveat introduced is that citizens are 'purchasing an aggregate enterprise that promises to create public value' (Moore, 1995, 54).

At this point, the differences between the two ideal types may appear relatively insignificant: However, Moore $(1995,39)$ provides a foundational account of the difference of the public sector based upon the unique nature of public goods, arguing that justifications for public goods can be divided into two types, or ways of 'framing' the justification, namely, direct justifications for the provision of amenities (the public library exists so that citizens can borrow from a collection that they as individuals cannot afford and that the private sector will not provide, for example) and stronger, more complex types of justifications that invoke general principles (rights-based arguments, for example) and quite difficult empirical questions, involving '... a long and uncertain causal chain from the point of view of a government intervention' that are 'common to public sector enterprises'. 
Moore $(2005,40)$ argues that to justify the provision of a particular amenity (library books, for example) 'the public sector seems discretionary'. However, for the second type, public sector activity seems necessary. Viewed according to the latter frame, for example, the library is more than merely an amenity because (for example) it forms part of a series of institutions which guarantee the literacy of the society, which in turn is essential for democracy, as well as evoking considerations of equity. Further, what is considered to be properly inside the perimeter of the latter kinds of goods can, if we so choose, decide the boundary of the public sector in any given context.

Finally, while Moore may wish to create Public Value by seeking a justification for greater managerial autonomy, this is not at the expense of the primacy of the authority of politics. He makes this absolutely clear:

Politics, and the laws that politics produce, deserve this pride of place for three reasons. First, it is the realm that managers must search to discover what purposes are deemed publically valuable and can, therefore, be practically and normatively sustained as the focus of their managerial efforts. It is in and through politics that they can discover and help shape their mandates for action. Second, political institutions grant public managers the resources they need to accomplish their operational purposes - including money and authority over their own organisations and over those beyond their organisations who can contribute to the managers' purposes. Third, it is to politics and law that public managers are both theoretically and practically accountable; their performance is graded and their reputations made within this realm (Moore, 1995, 105).

This is Moore's (1995) ultimate delineation of public and private organisations at the level of theory and expressed as such it appears quite arbitrary. However, we argue that it is significantly compromised when viewing both types of organisations from an operational perspective. It is to this that we now turn.

\subsection{Operational Similarity of Public-Private in Public Value}

Contrary to this radical distinction between the prescribed ambits for public and private organisations at the level of political theory, Moore explicitly seeks to inject the public sector with the preconditions for private sector value. To return to his original example of the librarian:

By discouraging [entrepreneurial] thoughts such as those the librarian is having, and the actions that could follow from her thoughts, society denies its public sector the key ingredient on which its private sector specifically relies to remain responsive, dynamic and value creating: namely the adaptability and efficiency that come from using the imaginations of people called managers to combine what they can sense of public demand with access to resources and control over operational capacity to produce public value (Moore, 1995, 19).

In encouraging public managers to enact this idea of value, clearly Moore (1995) demonstrates not merely a deep respect for the institutions of private property and the profit motive, but also the ethical comportment he entreats public sector managers to take from the private sector and conduct themselves by. Further, the transposable nature of his prescriptions is demonstrated in his recommendations for organisational behaviour. This includes, for example, the adoption of corporate strategy, its utility residing in taking into account different production units as part of a manager's purview and in dealing with outside challenges to the legitimacy of the organisation (Moore 1995, 106-134). Moore's normative theory also encourages managers to develop legitimacy and support for their organisation (rather than simply accept that which is mandated to it through the political sphere); to interface with the political system on the basis of 'continuous and interactive dialogue' (Moore, 1995, 75) and most significantly to act upon their knowledge of the 'distinct competence of their organisation - combined with what they are learning through their current operations about the needs of their clients and potential users' (Moore, 1995, 75). Moore (1995, 89-99) also discusses (in turn) the managerial utility of mission statements, 'identifying key political and administrative tasks', 'mobilizing internal and external support' and 'the degree of risk and exposure' for public organisations and devotes considerable attention to other types of 'political management', both inside organisations (garnering support from superiors and subordinates, for example) as well as interfacing with external organisations such as the media, interest groups and the legal system (Moore,1995, 118-134). These operational similarities point to the underlying ethical similarity of management in both sectors, which we now move to consider in more detail.

\section{Public Value: From Virtue Ethics to Civic Virtue?}

The apparent tension between (a) the theoretical account of Public Value and (b) the operational account recedes significantly when we examine the explicit conceptualisation of virtue that Moore (1995, 293-309) links to his theory. Moore $(1995,295)$ points out that public managers experience radically inconsistent (indeed incommensurate) 'images of virtue': On the one hand, the image of 'politically neutral competence' mandates that 'public officials are discouraged from holding their own views of what is right', yet on the other hand, 
'officials are morally obligated to have (and act on) their moral views'.

Yet Moore asserts that this is a false dichotomy based upon two misconceptions: First, that the actions of public managers are guided by 'clear, coherent and stable mandates' - this is rarely the case and, in general, public managers cannot 're-open' policy debates, rather they adapt to changes during implementation. Second, Moore $(1995,296)$ observed that public managers usually do not wish to put their views in abeyance, and even if entitled to contribute to the decision-making process and then forever hold their peace, their position will be one of resentment at any unfolding developments. He is forthright in his observations:

Because traditional images of virtue among public sector managers are founded on sand, they not only fail to provide useful guidance but also foster cynicism and hypocrisy ... the secret image of virtue among government managers becomes one of skilled advocates building powerful dykes protecting themselves... from the political tides that seep over the more gullible, dutiful bureaucrats ... In short, managers are judged by how skilfully they recruit a political constituency to support their preferred policy position, rather than by how creative they are at integrating or adapting to conflicting political forces (Moore, 1995, 299).

The intuitive accuracy of Moore's diagnosis ought to attract our attention, as indeed ought his solution, which is for public managers to contentiously take up their role as 'explorers commissioned by society to search for Public Value' based, in particular, on a principle of openness. While Moore's recommendations may sound glib, this may be because we assume that in being 'explorers' (Moore's phrase) public managers act as 'scouts' (our phrase) for potential opportunities of Public Value. This is a fundamental misinterpretation of his prescription (although we may be patterned to think of public servants in this way). Rather, we have to re-envisage the policy formulation and implementation process as both procedural and continuous, rather than output-driven, where accountability (or 'authorisation') is 'after the fact' as well as 'before the fact'; where there are both substantive (ethical) and operational risks in the decisions made, where obligations to one's subordinates have to be recognised and where at times the difficult moral question will not be resource allocation but 'how aggressively, and on behalf of what values, public managers should engage and respond to their political environments' (Moore, 1995, 302).

Moore is quite clear that 'in making such choices, managers expose themselves to moral risks' because all voices are entitled to be heard and as such to privilege one by acting upon it or valuing it more highly 'is making an important decision not only about what is publically valuable but about to whom they are democratically accountable' (Moore, 1995, 306). In this way, both Moore's (1995) diagnosis of public managerial behaviour and his prescriptions for it recognise that managers are moral agents 'creating value'.

In these observations we are alerted to the orchestrating role of public managers. This ethical stance $-\mathrm{a}$ virtue ethics, rather than an ethics based on an absolute, or deontological idea of the Public Interest, or upon the rational calculation of measured interests (utilitarian - see, for example, Crane and Matten, 2007, 86-117) is at the service of value creation rather than any other goal (the preservation of the bureaucracy; the directives of political overseers, on the political will of a particular class, for example). This account of value - which is derived from managers applying imagination in the context of authorising environments and organisations' capabilities, is (again) a mirror image of the account of value in the private sector - to the extent that Moore $(1995,52)$ argues that it can be quantified in precisely the same way and resonates strongly with contemporary accounts of management that have revitalised various types of leadership theory (for an overview, see Wallis and Dollery, 1999).

In our account of Moore's (1995) theory, which is at once both institutional as it is ethical, it is clear that Moore wanted to both explain and defend the unique nature of government and public management. However, at the same time, many of his prescriptions for public managers - in terms of their perception of the authorising environments (inclusive of the views of a range of actors) as well as their role in creating value, for example have an intuitive place in the changed circumstances in which businesses operate described by Scherer and Palazzo (2010). This is the case to the extent that the theory ought to provide the basis for conceptualising a normative framework which moves to incorporate broader responsibilities for business - in short, to move from a virtue ethics to provide the basis for a 'civic virtue' for private organisations.

Notwithstanding the intricate history of the idea of civic virtue both within the context of the modern nation state (see, for example, Almond and Verba, 1963), in the history of political ideas (see, in particular, Skinner, 1975) and in organisational theory (Barnard, 1938), initially, the idea of civic virtue as we are using it in this context is most readily explained if we refer to an augmented version of the 'strategic triangle' provided by Alford and O'Flynn (2009) in which the normative content of each constitutive realm is highlighted and applied exclusively to private organisations, as represented in Figure 2. 
Insert Figure 2 here

Examining Figure 2, the realm of virtue ethics resides in the production of value by managers themselves, namely how they organise their relationship to the full complexity of their 'task environment'. Importantly, this need not merely be value as measured by the private sector (customer satisfaction; share price) but on the contrary may involve all the complexities that Moore (1995) identifies and recommends for public managers as part of their role in creating public value. Our representation of it in Figure 2 is conceptually discrete: In practice, the production of value entails the operational flexibility of Moore's (1995) theory, inclusive of his recommendations for the ethical comportment of managers discussed above. Similarly, if we think of the organisational environment not as a bundle of physical assets but also as entailing a (malleable) corporate ethos which contributes to the definition of its capabilities for producing value, we can align this to the sphere of 'operational capabilities' in our adaptation of Alford and O'Flynn's Figure.

However, the idea of civic virtue is not directly transposable to the authorising environment in our adaptation of Alford and O'Flynn's Figure. As we have seen, and despite the protestations of some (for example Rhodes and Wanna, 2007; 2009), in Moore's (1995) theory, the explicitly political realm trumps both value-producing behaviour and organisational capabilities in the public sector. Moreover, while Moore's theory is public-sector specific, we argue that it ought to apply to business also, particularly in situations where the authorising environment is legitimate: The will of government ought to trump that of the private sphere.

Remember, however, that we are attempting to construct a normative framework for business in the changed conditions that Scherer and Palazzo (2010) have identified, namely where authorizing environments are at least fluid and may be problematic. In these environments, virtue for private managers resides not merely in the ethics they enact themselves, nor in their interface with their authorising environments (customers; shareholders). On the contrary: The primary virtue in these circumstances is a civic virtue, residing in the production of value resting between the three ideal-type normative spheres in our adaptation of Moore's theory. Conceptualised as such, civic virtue takes into account the ethos of individual managers and their organisations' capabilities, but conceptualises the authorising environment with a degree of complexity attendant to Moore's (1995) theory, inclusive of a range of other actors' views. The provision of different types of goods as determined by the different types of justifications attendant to them - basic amenities as well as those which have more complex justifications - taken together, constitute Public Value.

Further, as we have seen with Moore's (1995) theory, despite his staunch sanctioning of the legitimacy of political authority, the theory of Public Value still prescribes for managers what we have described as a 'box seat' in terms of decision-making. This entails that in acting courageously or in generating hope for their organisations (for example) managers may challenge the authority of the explicitly political sphere or indeed any other element of the particular authorising environment they find themselves in - as indeed Moore (1995) encourages them to do. Yet it also gives them scope for a significantly enlarged political role - the construction of a civic virtue - based on the legitimacy of their organisational processes within a broader context. We now return to this.

\section{From Corporate Social Responsibility to Corporate Political Responsibility}

In returning to the private sector with our critical reflections upon Moore's (1995) theory of Public Value, the first and most important observation we make is that Moore's (1995) strategic triangle of managerial decision-making is directly transposable to the context of private organisations' activities. In one sense, it is at this point that the comparison is at its least controversial: Moore (1995) borrowed heavily from the theory of managerial autonomy in private organisations and overlaid it upon the public sector where, as we have seen, some (for example Rhodes and Wanna, 2007) found the theory deeply concerning. Nevertheless, the usefulness of his conceptual scheme as a managerial tool of critical self-understanding in the private sector is, we assert, a feature of the theory.

However, more important in this context is the way the theory conceptualises what Moore (1995) denoted as the 'authorising environment' and private managers' interactions with this. This prescribed conceptualisation of the ethical terrain beyond the firm is clearly outside the responsibilities prescribed in the classical theory of the firm (the 'economic view' identified by Scherer and Palazzo $(2010,6)$ ). Further, it can also be distinguished from the more expansive 'instrumental' view, wherein CSR is regarded as a mechanism to achieve 'win-win' outcomes (through environmentally friendly production processes, selling healthier food, donating to charity and so on). It is also an advance upon the business ethics/normative stakeholder approach, in that rather than attempting to draw different perspectives into ambit of the firm (Scherer and Palazzo, 2010,7) then (rationally) weigh, assess and appease the competing interests of stakeholders within its ambit, management is necessarily directed both 
'outward and upward' (Moore, 1995, 17; emphasis added) to embrace an interface with the authorising environment, which will include both customers and shareholders but will necessarily include a range of other actors such as regulatory organisations (whether they be governments or not) NGOs, the media, interest groups and so forth. Additionally, we have argued that the procedural nature of the theory, when applied to private organisations' activities, moves from Moore's (1995) original prescription for virtue ethics to one incorporating an idea of civic virtue.

In order to flesh out this prescriptive application of Moore's (1995) theory, we apply it to the five elements that Scherer and Palazzo $(2010,8)$ identified as constitutive of the "new perspective" on corporate responsibility discussed in the introduction to this paper. The first of these is what they referred to as: "the emerging global institutional context for CSR: From national to global governance'. A transposition of Public Value to private organisations clearly provides a context-dependent, normative theory of organisational and managerial ethical behaviour where the authority of government has not yet been fully established, or (paradoxically) where it has been eroded due to regulatory reform, or alternatively where corporations have chosen to take on roles which can be described as political (such as the '... housing, cultural preservation and heritage...' roles that BHP Billiton nominated in its Supplementary Sustainability Information 2010b report). However, we would caution that the extent of these phenomena and the declining normative relevance of the liberal nation-state ought not to be overestimated. The tendency to paste a narrative of globalisation into accounts of change is teleological and reductionist. Further, it denies the central place that the liberal government still occupies in the oversight and regulation of business, both within and outside national boundaries, both in the form of negotiated contracts and agreements and their enforcement and the normative place that some would argue it ought to hold. Moreover, while writers such as Scherer and Palazzo (2010, 5; see also Lux, et al., 2011) emphasise activity 'above and beyond' the nation state, we would point to those myriad of institutional forms that exist 'below and inside' that same moral perimeter to which Public Value is equally relevant. In both these types of situations, where the framework of government is less imminent, it would appear Public Value is well suited as a theory of corporate political responsibility.

The second and related feature of the new perspective on corporate responsibility is what Scherer and Palazzo's (2010) termed 'CSR as self-regulation: from hard law to soft law'. This is exemplified by what we have noted is the shift from (legal) government to multiple lineages of private and corporate governance and, in particular, self-regulation. Again, Public Value provides a context-dependent model of self-regulation for corporate enterprises based upon the centrality of (virtuous) managerial authority. Importantly it does not purport to guarantee that this self-governance will be faultless; on the contrary: The nature of virtue ethics necessarily entails the possibility of failure, both ethical and organisational. However, the framework provided by Moore's strategic triangle sets in place a series of yardsticks by which to continually assess and reassess the worth of actions.

Public Value also clearly entails Scherer and Palazzo's $(2010,9)$ third shift, 'the expanding role of CSR: from liability to social connectedness'. While Scherer and Palazzo emphasise the need for an ethical framework in ambivalent situations where MNCs are involved, again, we would emphasise that this point can be equally applied in local arenas. Public-private partnerships and other emergent forms of service provision at sub-national levels (see, for example, Grant and Fisher, 2011) necessarily entail a negotiation of the overlapping ambits of governments, community groups and private companies. In these contexts, Public Value again offers a framework for private managers/CEOs and their organisations.

However, it is with respect to the final two shifts identified by Scherer and Palazzo - 'the changing conditions of corporate legitimacy: from cognitive and pragmatic legitimacy to moral legitimacy' and 'the changing societal foundations of CSR: From liberal democracy to deliberative democracy' (Scherer and Palazzo, 2010, 9) that Public Value appears to be most suited. This prescribed role for decision-making not only incorporates a post-foundational account of knowledge (or what Rorty (1991) termed 'the priority of democracy over philosophy'). It also entails a procedural theory of deliberative decision-making which some - for example, Stoker (2006) read as a democratic process. Yet when we come to apply Public Value to private organisations it may well be that all views will not be equal - indeed, the authorising environment may necessarily prioritise both consumers and shareholders over other participants (in the same way that Moore asserts the supremacy of the explicitly political as legitimately representative of citizens' interests in his theory of Public Value). Further, it also gives to management a pivotal role in decision-making such that, as a necessary requirement of the theory, it is not compatible with some conceptualisations of democratic politics (Dryzek's (1990) theory of 'discursive democracy', for example).

Nevertheless, we have seen that for Moore's (1995) theory of Public Value, the institutions of liberal democracy, 
inclusive of the explicitly political realm, but also of other kinds of organisations (the media, interest groups, etc.) form a changing context within an organisational theory of deliberative decision-making. In this sense, Moore's theory has more in common with traditions of deliberative democratic civil association, in particular the work of Paul Hirst (1997; as cited by Stoker, 2006) and its defence of corporate democratic decision-making procedures.

\section{Concluding Remarks}

In our account of the way in which Moore's theory of Public Value addresses a broad range of challenges to CSR identified by Scherer and Palazzo (2010), we have emphasised the way that the original theory, then our extrapolation from it, assists in the re-conceptualisation of the roles of private sector managers and, in particular, how Moore's (1995) account of virtue ethics can be translated into an account of civic virtue for these changed circumstances. However, the attendant reliance upon managerial assessments does not entail that all political authority is transposed onto private organisations. As we have seen, Moore (1995) made the distinction between two different types of public goods: amenities on the one hand (which do not disturb the pre-existing allocation of preferences) and those based upon ideas of justice and fairness on the other, where the deliberative and justifiable organisation of preferences becomes a legitimate, although contested role for management.

This distinction serves as a useful way to delineate the activities of corporations and their managers when assessing the appropriate scope of their actions. This is where Public Value assists - not merely in recognising that there is a qualitative distinction between providing the two different types of goods, but in providing a model for proceeding when faced with situations which require managers to justify roles or activities which have previously fallen outside the ambit of business.

Yet the usefulness of the theory in terms of providing an account of politics for private organisations ought not distract us from the centrality of Moore's account of ethical value creation on both sides of public-private divide, namely the exercising of the managerial imagination, the application of these imaginings and the possibility of success, failure or in all probability something in between. It is Moore's placement of this fundamental insight into a situation-dependent, normative theory of organisational behaviour which forms the essence of the appeal and applicability of his work.

\section{References}

Alford, J., \& O'Flynn, J. (2009). Making sense of public value: Concepts, critiques and emergent meanings. International Journal of Public Administration, $32(3 \& 4), \quad 171-191$. http://dx.doi.org/10.1080/01900690902732731

Almond, G. A., \& Verba, S. (1963). The civic culture: Political attitudes and democracy in five nations. New Jersey: Princeton University Press.

AMP (2011). Sustainability [Online] Available: http://www.ampcapital.com.au/research-centre/sustainability-research/sustainability-papers.asp (8 May 2011)

Barnard, C. (1938). The functions of the executive. Cambridge: Harvard University Press.

BHP Billiton. (2010a). Sustainable development. [Online] Available: http://www.bhpbilliton.com/bb/sustainableDevelopment.jsp (8 May 2011)

BHP Billiton. (2010b). Our strategy delivers: sustainability supplementary information. [Online] Available: http://www.bhpbilliton.com/bbContentRepository/docs/sustainabilitySupplementaryInformation2010.pdf (8 May 2011)

British American Tobacco. (2011). Our approach to sustainability. [Online] Available: http://www.bat.com/group/sites/UK_3MNFEN.nsf/vwPagesWebLive/DO726NTL?opendocument\&SKN=1 (8 May 2011)

Charles, M. B., Jong, M. de \& Ryan, N. (2010). Public values in Western Europe: A temporal perspective. The American Review of Public Administration, 41(1), 75-91. http://dx.doi.org/10.1177/0275074010361529

Crane, A., \& Matten, D. (2007). Business ethics: Managing corporate citizenship and sustainability in the age of globalisation (2nd ed.). Oxford: Oxford University Press.

Cutler, A. C. (2001). Critical reflections on the Westphalian assumptions of international law and organisation: A crisis of legitimacy? Review of International Studies, 27, 133-50. http://dx.doi.org/10.1017/S0260210500001339

Davis, K. (1960). Can business afford to ignore corporate social responsibilities? California Management Review, 2, 70-76. 
Davis, K. (1967). Understanding the social responsibility puzzle. Business Horizons, 10(4), 45-51.

Dryzek, J. (1990). Discursive democracy. Politics, policy and political science. Cambridge: Cambridge University Press.

Friedman, M. (1970). The social responsibility of business to increase its profit. In T. Donaldson and P. H. Werhane (Eds.). Ethical issues in business: A philosophical approach (pp. 217-23). Englewood Cliffs, New Jersey: Prentice Hall.

Gains, F., \& Stoker, G. (2009). Delivering 'public value': implications for accountability and legitimacy. Parliamentary Affairs, 62(3), 438-455. http://dx.doi.org/10.1093/pa/gsp007

Garriga, E., \& Melé, D. (2004). Corporate social responsibility theories: Mapping the territory. Journal of Business Ethics, 53(1-2), 51-71. http://dx.doi.org/10.1023/B:BUSI.0000039399.90587.34

Grant, B., \& Fisher, J. (2010). Public value: Positive ethics for Australian local government. Journal of Economic and Social Policy, 13(3). Article 7. [Online] Available: http://epubs.scu.edu.au/jesp/vol14/iss2/7/

Hearfield, C., \& Sorensen, T. (2009). Regional economic governance: A technology of government or regional autonomy in New South Wales?'. Space and Polity, 13(2), 93-107. http://dx.doi.org/10.1080/13562570902999759

Lux, S., Crook, T. R., \& Woehr, D. J. (2011). Mixing business with politics: A meta-analysis of the antecedents and outcomes of corporate political activity. Journal of Management, 37(1), 223-247. http://dx.doi.org/10.1177/0149206310392233

MacDonald's Australia. (2010). CR \& $\quad$ S Report. [Online] Available: http://mcdonalds.com.au/sites/mcdonalds.com.au/files/images/MCD_CR\&S_Chapter8.pdf (8 May 2011)

Matten, D., \& Crane, A. (2005). Corporate citizenship: Towards an extended theoretical conceptualisation. Academy of Management Review, 30, 66-179. [Online] Available: http://www.jstor.org/stable/10.2307/20159101

Meynhardt, T., \& Metlemann, J. (2009). Pushing the envelope: Creating public value in the labour market: An empirical study on the role of middle managers. International Journal of Public Administration, 32(3\&4), 274-312. http://dx.doi.org/10.1080/01900690902732806

Moore, M. (2005). Creating public value. Strategic management in government. Cambridge: Harvard University Press.

Nye, J. S. (1990). Soft power. Foreign Policy, 80. 153-71.

Nye, J. S. (2004). Soft power: The means to success in world politics. New York: Public Affairs.

O'Flynn, J. (2007). From new public management to public value: Paradigmatic change and managerial implications. Australian Journal of Public Administration, 66(3), 353-366. http://dx.doi.org/10.1111/j.1467-8500.2007.00545.x

Plant, J. F., Stalebrink, O. J., \& Vasavada, T. (2010). Public values, public official associations, and professionalism: A cross national analysis. The American Review of Public Administration. Advance online publication. http://dx.doi.org/10.1177/0275074009360821

Reich, R. (2008). Supercapitalism. The transformation of business, democracy and everyday life. Carlton North, Victoria: Scribe.

Rhodes, R. A. W., \& Wanna, J. (2007). The limits to public value, or rescuing responsible government from the Platonic guardians. Australian Journal of Public Administration, 66(4), 406-421. http://dx.doi.org/10.1111/j.1467-8500.2007.00553.x

Rhodes, R. A. W., \& Wanna, J. (2009). Bringing the politics back in: Public value in Westminster parliamentary government. Public Administration, 87(2), 161-183. http://dx.doi.org/10.1111/j.1467-9299.2009.01763.x

Rorty, R. (1991). Objectivity, relativism and truth. Philosophical papers volume 1. Cambridge: Cambridge University Press.

Samaratunge, R., \& Wijewardena, N. (2009). The changing nature of public values in developing countries. International Journal of Public Administration, 32(3\&4), 313-327. http://dx.doi.org/10.1080/01900690902732947

Scherer, A. G., \& Palazzo, G. (2010). The new role of business in a globalised world: A review of a new perspective on CSR and its implications for the firm, governance and democracy. Journal of Management 
Studies. Advance online publication. http://dx.doi.org/10.1111/j.1467-6486.2010.00950.x

Skinner, Q. (1978). The foundations of modern political thought. Volume one: The Renaissance. Sydney: Cambridge University Press.

Spano, A. (2009). Public value creation and management control systems. International Journal of Public Administration, 32(3\&4), 328-348. http://dx.doi.org/10.1080/01900690902732848

Stoker, G. (2006). Public value management: A new narrative for networked governance? American Review of Public Administration, 36(1), 41-57. http://dx.doi.org/10.1177/0275074005282583

Talbot, C. (2009). Public value: The next "Big Thing" in public management? International Journal of Public Administration, 32(3\&4), 167-170. http://dx.doi.org/10.1080/01900690902772059

Wallis, J., \& Dollery, B. E. (1999). Market Failure, Government Failure, Leadership and Public Policy. Basingstoke: MacMillan Press.

Wallis, J., \& Gregory, R. (2009). Leadership, accountability and public value: Resolving a problem in 'new governance'? International Journal of Public Administration, 32(3\&4), 250-273. http://dx.doi.org/10.1080/01900690902732608

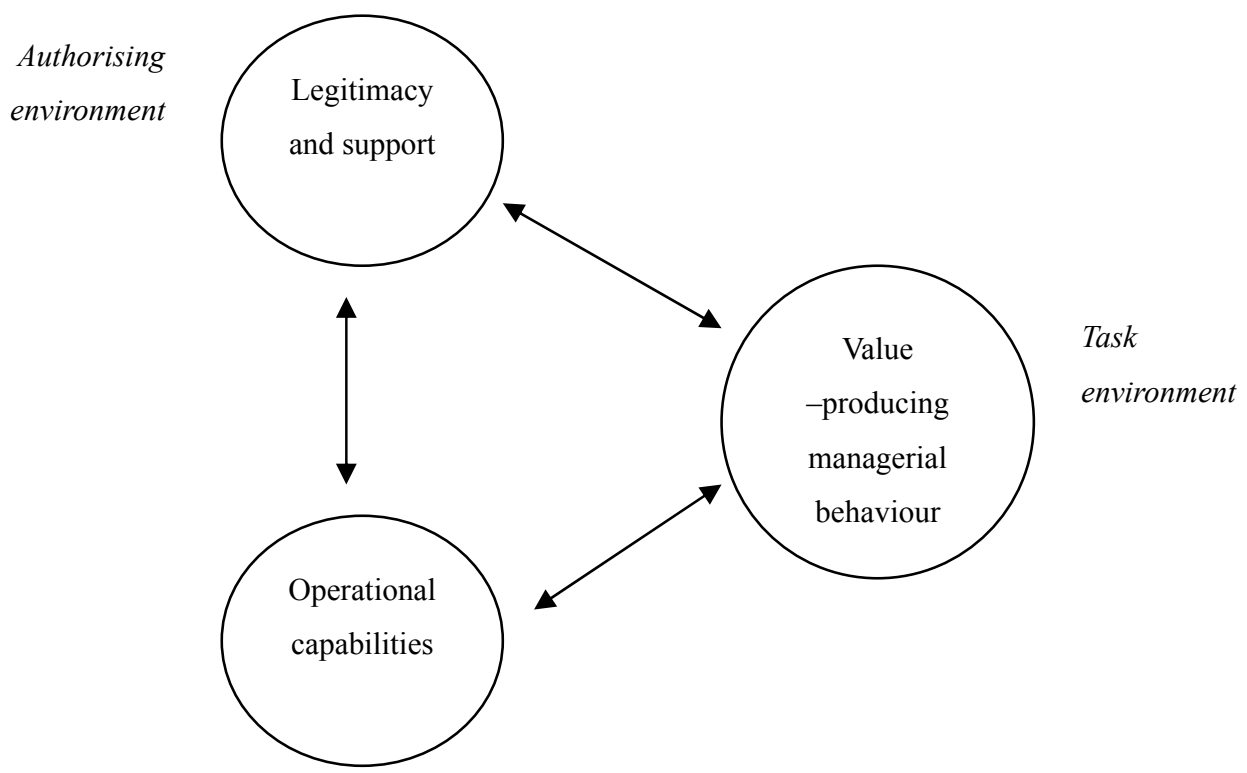

Figure 1. Moore's (1995) 'strategic triangle'

Source: Alford and O'Flynn, 2009, 173. 


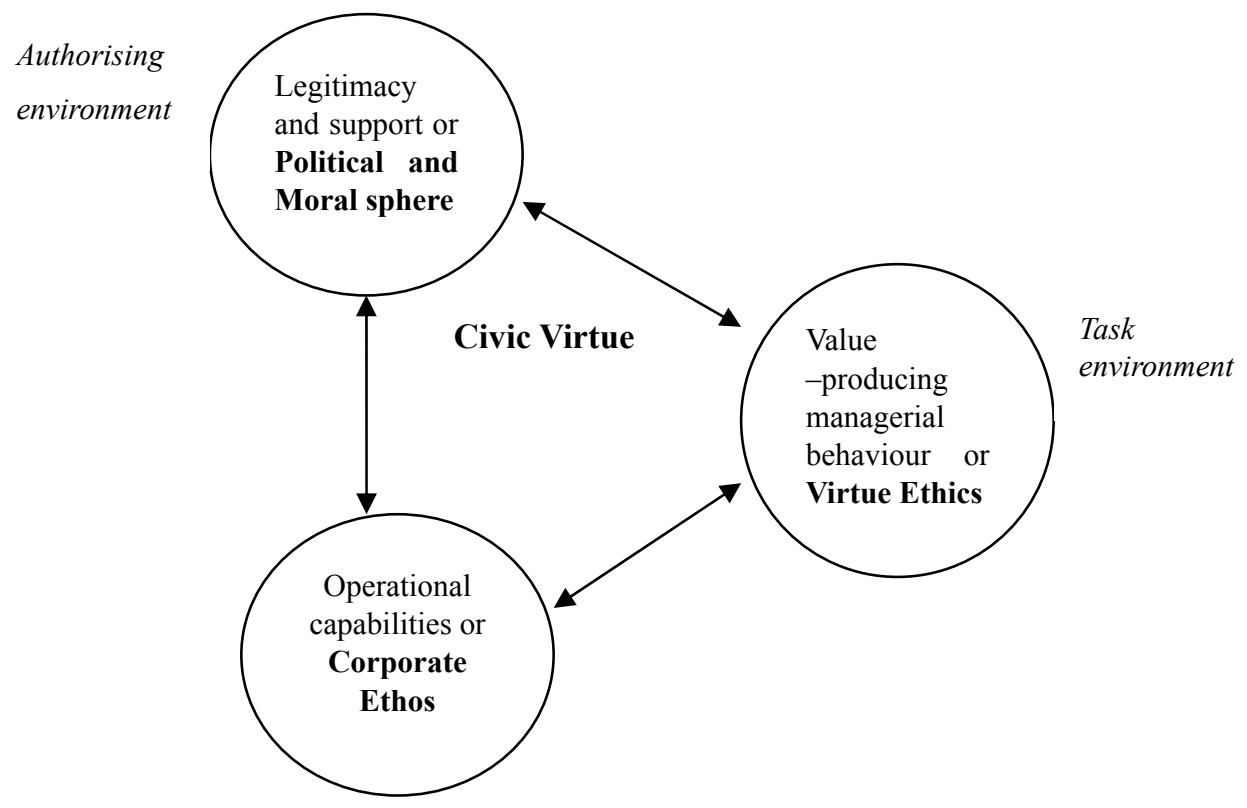

Figure 2. Adaptation of Moore's (1995) 'strategic triangle'

Source: Adapted from Alford and O’Flynn, 2009: 173. 